\title{
Growth and Gas Exchange by Lettuce Stands in a Closed, Controlled Environment
}

\author{
R.M. Wheeler, C.L. Mackowiak ${ }^{1}$, J.C. Sager, N.C. Yorio ${ }^{1}$, and W.M. Knott \\ National Aeronautics and Space Administration Biomedical Operations and Research Office, Kennedy \\ Space Center, FL 32899 \\ W.L. Berry \\ Laboratory of Biomedical and Environmental Sciences, University of California, Los Angeles, CA 90024
}

\begin{abstract}
Additional index words. Lactuca sativa, CELSS, controlled ecological life support system, evapotranspiration, photosynthesis, respiration

Abstract. Two studies were conducted in which 'Waldmann's Green' lettuce (Lactuca sativa L.) was grown hydroponically from seed to harvest in a large $\left(20-\mathrm{m}^{2}\right)$, atmospherically closed growth chamber for the National Aeronautics and Space Administration's controlled ecological life support system (CELSS) program. The first study used metal-halide (MH) lamps $\left[280 \mu \mathrm{mol} \cdot \mathrm{m}^{-2} \cdot \mathrm{s}^{-1}\right.$ photosynthetic photon flux (PPF)], whereas the second used high-pressure sodium (HPS) lamps $\left(293 \mu \mathrm{mol} \cdot \mathrm{m}^{-2} \cdot \mathrm{s}^{-1}\right)$. Both studies used a 16-hour photoperiod, a constant air temperature (22 to $23 \mathrm{C}$ ), and $1000 \mu \mathrm{mol}^{\circ} \mathrm{mol}-$ ${ }^{1} \mathrm{CO}_{2}$ during the light period. In each study, canopy photosynthesis and evapotranspiration (ET) rates were highly correlated to canopy cover, with absolute rates peaking at harvest ( 28 days after planting) at $17 \mu \mathrm{mol} \mathrm{CO}_{2} / \mathrm{m}^{2}$ per sec and 4 liters $\cdot \mathbf{m}^{-2} \cdot$ day $^{-1}$, respectively. When normalized for actual canopy cover, photosynthesis and ET rates per unit canopy area decreased with age (between 15 and 28 days after planting). Canopy cover increased earlier during the study with HPS lamps, and final shoot yields averaged $183 \mathrm{~g}$ fresh mass (FM)/plant and $8.8 \mathrm{~g}$ dry mass (DM)/plant. Shoot yields in the first study with MH lamps averaged $129 \mathrm{~g} \mathrm{FM} /$ plant and $6.8 \mathrm{~g} \mathrm{DM} / \mathrm{plant}$. Analysis of leaf tissue showed that ash levels from both studies averaged $22 \%$ and K levels ranged from $15 \%$ to $17 \%$ of tissue DM. Results suggest that lettuce should be easily adaptable to a CELSS with moderate lighting and that plant spacing or transplant schemes are needed to maximize canopy light interception and sustain efficient $\mathrm{CO}_{2}$ removal and water production.
\end{abstract}

Lettuce is one of several candidate species under study for use in controlled ecological life support systems (CELSSs) proposed for human life support in space. Several criteria favor the use of lettuce as a life-support crop, including its versatility as a fresh salad crop, its adaptability to controlled-environment cultivation, and its low growth habit with a defined shoot shape (Tibbitts and Alford, 1982). In addition, an extensive information base is available on lettuce growth and environmental physiology in controlled environments (Barta and Tibbitts, 1991; Craker and Seibert, 1983; Hammer et al., 1978; Hicklenton and Wolynetz, 1987; Knight and Mitchell, 1983, 1988a, 1988b; Sager, 1984; Tibbitts et al., 1983), although not in closed systems.

In this paper we present results from two baseline studies conducted with lettuce in a large $\left(20-\mathrm{m}^{2}\right)$, atmospherically closed chamber analogous to what might be used in a functioning CELSS. The objective of these studies was to track gas, water, and nutrient balances along with productivity of entire lettuce stands from seeding to harvest. Environmental conditions for growth were selected after surveying the literature (references cited above), university laboratories, and commercial operations having experience with growing lettuce. Because of the exploratory nature of the studies, several conditions changed between the first and second studies-most notably, the use of high-pressure sodium (HPS) lamps instead of metal-halide (MH) lamps and the addition of

\footnotetext{
Received for publication 10 June 1993. Accepted for publication 9 Sept. 1993. Any opinions, findings, and conclusions or recommendations expressed in this publication do not necessarily reflect the views of the National Aeronautics and Space Administration. We thank Lisa Siegriest and Katrina Chetirkin for horticultural assistance in the studies and Glenn Markwell, Russ Fortson, Joe Martinez, and Joe Benjamin for computer and mechanical systems assistance. The cost of publishing this paper was defrayed in part by the payment of page charges. Under postal regulations, this paper therefore must be hereby marked advertisement solely to indicate this fact.

${ }^{1}$ The Bionetics Corp., Kennedy Space Center, FL 32899.
}

nutrient solution temperature control. Results from these and related studies will be used to assess the feasibility and reliability of using higher plants and the associated hardware and control systems for human life support in space.

\section{Materials and Methods}

Studies were conducted in National Aeronautics and Space Administration's (NASA's) biomass production chamber (BPC) located at Kennedy Space Center, Fla. The cylindrical chamber (7.5 $\mathrm{m}$ high and $3.7 \mathrm{~m}$ in diameter) formerly served as a hypobaric test chamber during NASA's Mercury Project and has since been adapted for plant studies (Prince and Knott, 1989; Prince et al., 1987). The internal volume including air ducts equaled $113 \mathrm{~m}^{3}$ and, when closed, atmospheric leakage was $\approx 10 \%$ of the volume per day $(0.4 \% \mathrm{vol} / \mathrm{h})$.

Plants were supported inside the chamber by four, vertically stacked annular shelves, with each shelf supporting $160.25-\mathrm{m}^{2}$ (10-cm-deep) acrylonitrile-butadiene-styrene (ABS) plastic culture trays. Trays provided a basal rooting area of $4 \mathrm{~m}^{2}$ per shelf and $16 \mathrm{~m}^{2}$ for the entire chamber. Direct measurements of projected groundcover throughout growth indicated that actual canopy area reached $\approx 20 \mathrm{~m}^{2}$ at final harvest due to leaves extending beyond the basal tray dimensions.

Cultural approach. In each of the two studies reported, 'Waldmann's Green' lettuce plants were started by directly sowing dry seed between two nylon (Nitex) fabric wicks supported $\approx 4$ $\mathrm{cm}$ above the bottom of culture trays. Wicks were supported by juxtaposing white-on-black polyethylene plastic strips suspended through $2.5-\mathrm{cm}$-diameter holes in white ABS plastic tray covers (Prince and Knott, 1989). All new wicks were prerinsed with ethanol and deionized water to remove potential phytotoxins (Wheeler et al., 1985). Two to three seeds were planted at each of six positions on the $0.25-\mathrm{m}^{2}$ tray covers. After planting, trays were 
covered with white, translucent acrylic covers for 2 days to maintain high humidity during seedling establishment. Seedlings were thinned to one per position (i.e., six per tray) 7 days after planting (DAP).

Nutrient solution was provided to each culture tray using the recirculating nutrient film technique (Graves, 1981) with a complete nutrient solution with nitrate as the sole $\mathrm{N}$ source (Table 1). Each of the four shelves with their 16 culture trays was supplied from a separate nutrient solution with circulating pumps and reservoirs situated immediately outside the chamber (Prince et al., 1987). Head spaces of the reservoirs were vented to the main chamber to maintain atmospheric closure. Solution $\mathrm{pH}$ was monitored continuously and maintained between 5.8 and 6.0 by automatically adding $0.4 \mathrm{M}$ nitric acid. Solution electroconductivity was monitored continuously and maintained near $0.12 \mathrm{~S} \cdot \mathrm{m}^{-1}$ by automatically adding a complete nutrient stock solution. Water lost to evapotranspiration was replenished daily by adding deionized water to the reservoirs.

For the first study, nutrient solution temperatures were not controlled and averaged $26.3 \pm 1.7 \mathrm{C}$, ranging from 23 to $29 \mathrm{C}$, depending on ambient temperature effects on external tanks and plumbing lines. For the second study, stainless-steel (alloy 316) coils were submersed into the reservoirs to control temperature. Nutrient solution temperatures were maintained constant, with a final average of $25.6 \pm 0.6 \mathrm{C}$

Environmental conditions. Lighting for the first study was provided by MH lamps (400-W Venture ProArc; Venture Lighting International., Cleveland) electronically dimmed with dimming ballasts (Wide-Lite, San Marcos, Texas), with the photosynthetic photon flux (PPF) averaging $280 \mu \mathrm{mol} \cdot \mathrm{m}^{-2} \cdot \mathrm{s}^{-1}$ at the top of the plant canopy. Lighting for the second study was provided by HPS lamps (400-W Philips Ceramalux, Philips Lighting Corp., Bloomfield, N.J.; or GELucalox, General Electric Co., Cleveland), also dimmed with PPF averaging $293 \mu \mathrm{mol} \cdot \mathrm{m}^{-2} \cdot \mathrm{s}^{-1}$. PPF levels were monitored at each of 64 tray positions weekly using a quantum sensor (model LI-190, LI-COR, Lincoln, Neb.) and were adjusted as needed using dimming controls. A 16-h light/8-h dark photoperiod was used for both studies, providing 16 to $17 \mathrm{~mol} \cdot \mathrm{m}^{-2} \cdot$ day $^{-1} \mathrm{PPF}$.

Air temperature (taken from four positions within the chamber) averaged $22.5 \pm 0.5 \mathrm{C}$ ( $\mathrm{sD}$ between the four sensor positions in the chamber) in the light and $22.1 \pm 0.4 \mathrm{C}$ in the dark for the first study, and $22.6 \pm 0.4 \mathrm{C}$ in the light and $22.4 \pm 0.2 \mathrm{C}$ for the second study. Relative humidities averaged $80 \% \pm 4 \%$ in the light and $81 \% \pm 3 \%$ in darkness for the first study, and $71 \% \pm 3 \%$ in the light and $75 \%$ $\pm 2 \%$ in darkness for the second study. Carbon dioxide concentration of the atmosphere was maintained at $1000 \mu \mathrm{mol} \cdot \mathrm{mol}^{-1}(0.1$ $\mathrm{kPa}$ ) during light cycles by adding pure $\mathrm{CO}_{2}$. Carbon dioxide levels were not controlled during dark cycles and rose in response to plant respiration (Wheeler, 1992). When lamps were started each day,

Table 1. Nutrient solution composition for lettuce studies.

\begin{tabular}{lccc}
\hline \hline \multicolumn{2}{c}{$\begin{array}{c}\text { Macronutrients } \\
(\mathrm{mM})\end{array}$} & \multicolumn{3}{c}{$\begin{array}{c}\text { Micronutrients } \\
(\mu \mathrm{M})\end{array}$} \\
\hline $\mathrm{N}$ & 7.5 & $\mathrm{Cl}$ & 187.4 \\
$\mathrm{P}$ & 0.5 & $\mathrm{Fe}$ & $60.0^{\mathrm{z}}$ \\
$\mathrm{K}$ & 3.0 & $\mathrm{Mn}$ & 3.7 \\
$\mathrm{Ca}$ & 2.5 & $\mathrm{Zn}$ & 0.64 \\
$\mathrm{Mg}$ & 1.0 & $\mathrm{Cu}$ & 0.52 \\
$\mathrm{~S}$ & 1.0 & $\mathrm{~B}$ & $4.75^{\mathrm{y}}$ \\
& & $\mathrm{Mo}$ & 0.01 \\
\hline
\end{tabular}

${ }^{\mathrm{z}}$ From HEDTA chelate.

${ }^{\mathrm{y}}$ Decreased to $1.2 \mu \mathrm{M}$ for second study.
$\mathrm{CO}_{2}$ levels quickly decreased to the $1000 \mu \mathrm{mol} \cdot \mathrm{mol}^{-1}$ setpoint, at which controlled additions of $\mathrm{CO}_{2}$ were reinitiated. All $\mathrm{CO}_{2}$ added to the chamber atmosphere was passed through columns of potassium permanganate-coated pellets (Air Repair Products, Stafford, Texas) to remove possible hydrocarbon contaminants (Morison and Gifford, 1984). Oxygen concentrations were monitored, but not controlled and generally remained near $21 \%(21 \mathrm{kPa})$ throughout the study. Although the chamber was closed for most of the study, $\mathrm{O}_{2}$ concentrations did not increase because the chamber typically was entered daily for maintenance and measurements, which caused internal $\mathrm{O}_{2}$ levels to equilibrate with external ambient levels.

Experimental measurements. Beginning 15 DAP, shoot (head) diameters were measured manually for each plant along two axes offset by $90^{\circ}$. Measurements were repeated at $\approx 2$-day intervals thereafter. Total projected canopy cover was calculated by $\pi(\mathrm{d} / 2)^{2}$ $\times$ (no. plants), where $\mathrm{d}=$ the average shoot (head) diameter.

Plants were harvested at 28 DAP and shoot fresh mass (FM) was measured. Roots from all plants and one shoot from each of the 64 trays were oven dried at $70 \mathrm{C}$ for $48 \mathrm{~h}$ and the average percent dry mass (DM) for these shoots was then used to calculate the DM of the remaining, undried shoots. In addition to the final harvest at 28 DAP, four plants (one from each shelf) were harvested at 2-day intervals beginning at 16DAP in the second study. Duplicate tissue samples from the final harvest for both studies were ground with a Wiley mill (2-mm screen) and analyzed for proximate nutritional composition (Nutrition International, Dayton, N.J.). Proximate analyses followed standard Association of Official Analytical Chemists procedures (1984) and included the following: moisture by vacuum oven, ash by muffle furnace, protein by Kjeldahl $\mathrm{N}$ (6.25 conversion factor), crude fiber by digestion and gravimetric technique, fat by ether extraction, and carbohydrate by difference. Dietary energy equivalents were calculated by assigning $4 \mathrm{kcal} \cdot \mathrm{g}^{-}$ ${ }^{1}$ carbohydrate, $4 \mathrm{kcal} \cdot \mathrm{g}^{-1}$ protein, and $9 \mathrm{kcal} \cdot \mathrm{g}^{-1}$ fat. Four dried tissue samples from each study also were analyzed in triplicate for elemental composition using inductively coupled plasma spectroscopy (Alexander and McAnulty, 1981).

Beginning at $\approx 15$ DAP, plants were sufficiently large for stand respiration to cause a measurable increase in $\mathrm{CO}_{2}$ concentration during the dark period. This rise in concentration was followed by a drawdown to the $1000 \mu \mathrm{mol} \cdot \mathrm{mol}^{-1}$ setpoint after the lamps came on each day. Slopes of 1-h segments of these diurnal changes in $\mathrm{CO}_{2}$ concentration were used to calculate stand respiration and net photosynthesis rates using a closed system approach (Wheeler, 1992). With a leakage rate of $0.4 \%$ chamber vol $/ \mathrm{h}, \mathrm{CO}_{2}$ loss from the chamber was $<0.2 \mu \mathrm{mol} \cdot \mathrm{m}^{-2} \cdot \mathrm{s}^{-1}$; hence, leakage was ignored in $\mathrm{CO}_{2}$-exchange calculations. Data from the first $20 \mathrm{~min}$ after the dark-light or light-dark transitions were avoided for calculations to allow adequate time for environmental equilibration and to avoid any pressure transients.

Stand evapotranspiration (ET) rates were tracked daily by recording the amount of water added to the nutrient solution to bring the reservoirs to a fixed volume plus the volume of nutrient concentrate and acid added. Stand $\mathrm{CO}_{2}$ exchange and ET rates were expressed either on an absolute basis, assuming $20 \mathrm{~m}^{2}$ was available for stand growth, or normalized for actual canopy cover when direct area measurements were available.

\section{Results}

Beginning at 15 DAP, shoot diameters and total canopy cover of the lettuce stands increased rapidly (Fig. 1). Shoot diameters and total canopy cover increased earlier in the second study with HPS 
lamps than in the first study with $\mathrm{MH}$ lamps. The faster start by plants in the second study amounted to an advantage of 1 to 2 days in development compared to plants in the first study (Fig. 1).

Time-course net photosynthesis and dark-period respiration rates for the stands in each study are presented in Fig. 2. Net photosynthesis rates for the entire $20 \mathrm{~m}^{2}$ of planted area (absolute rates) were low initially because of the low amount of photosynthetically active radiation intercepted by the canopy (Figs. 1 and 2). Beginning at $\approx 15$ DAP, absolute rates increased steadily to $\approx 17$ $\mu \mathrm{mol} \cdot \mathrm{m}^{-2} \cdot \mathrm{s}^{-1}$ at harvest for both studies (Fig. 2). The increase in photosynthetic rate with time slowed slightly near 23 days in the second study and 24 days in the first study, which corresponded closely to when leaves between adjacent plants began to overlap. As with net photosynthesis, absolute rates of dark-period respiration were low initially but gradually increased as stand biomass increased (Fig. 2). Normalized photosynthetic rates (i.e., rates per unit area of projected canopy cover) were highest at $16 \mathrm{DAP}(\approx 25$

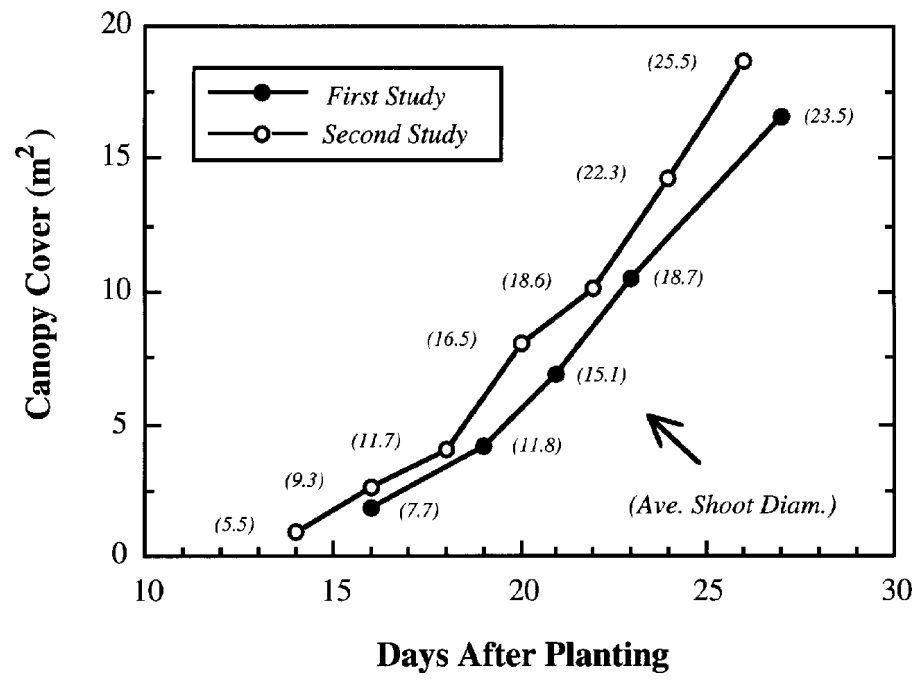

Fig. 1. Canopy cover over time for two lettuce plantings. Areas were determined by measuring shoot diameters (shown in $\mathrm{cm}$ ) to calculate single plant canopy cover and then multiplying by the total number of plants.

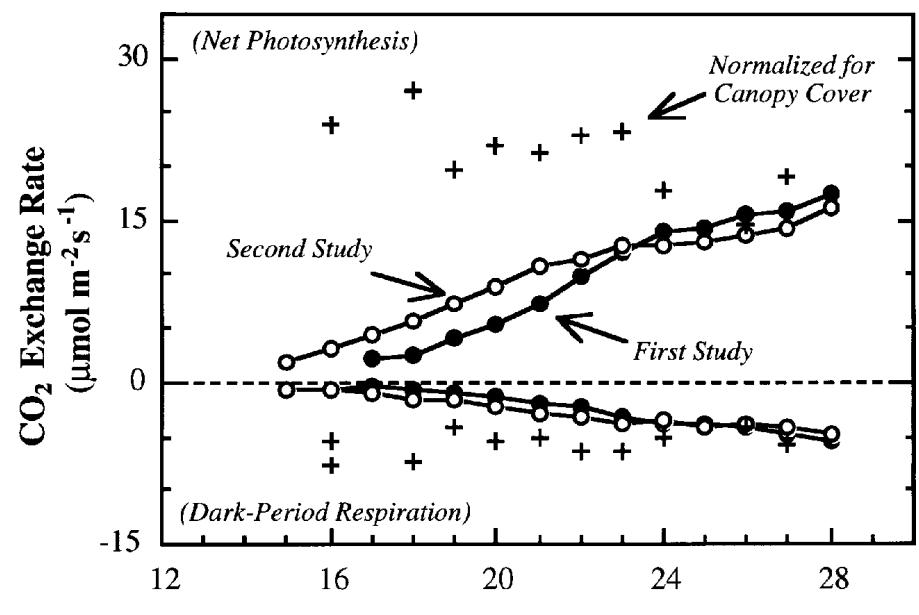

Days After Planting

Fig. 2. Carbon dioxide-exchange rates for two lettuce plantings over time. Rates during the light period are shown as positive values (net photosynthesis), while rates during the dark period are shown as negative values (dark-period respiration). Rates for the entire $20-\mathrm{m}^{2}$ area of the chamber are shown with symbols connected by lines; rates normalized to the actual canopy cover for both studies are shown as unconnected + symbols. $\left.\mu \mathrm{mol} \cdot \mathrm{m}^{-2} \cdot \mathrm{s}^{-1}\right)$, when gas exchange was first detectable, and then showed a general decline until plants were harvested at 28 DAP (Fig. 2). Likewise, normalized dark-period respiration rates were highest when plants were young and then declined slightly with age (Fig. 2).

Carbon dioxide uptake from stand photosynthesis was detectable sooner in the second study than in the first, following the trends in canopy cover between the two studies (Figs. 1 and 2). The correlation between stand $\mathrm{CO}_{2}$ uptake and canopy cover could be described by the quadratic equations $\mathrm{y}=24.45 \mathrm{x}-0.3 \mathrm{x}^{2}\left(R^{2}=0.99\right)$ in the first study, and $\mathrm{y}=29.42 \mathrm{x}-0.79 \mathrm{x}^{2}\left(R^{2}=0.99\right)$ in the second study (Fig. 3). Before canopy cover reached $10 \mathrm{~m}^{2}(\approx 22 \mathrm{DAP}), \mathrm{CO}_{2}$ uptake showed a near-linear increase with increasing canopy cover (Figs. 1 and 3).

ET rates for the lettuce stands over time are shown in Fig. 4. As with stand $\mathrm{CO}_{2}$ exchange, absolute ET rates increased quadratically with the increase in canopy cover: $\mathrm{y}=17.15+5.71 \mathrm{x}-0.11 \mathrm{x}^{2}$ $\left(R^{2}=0.99\right)$ for the first study and $\mathrm{y}=18.44+5.24 \mathrm{x}-0.10 \mathrm{x}^{2}\left(R^{2}=\right.$ 0.99 ) for the second study (Fig. 5). When normalized for canopy

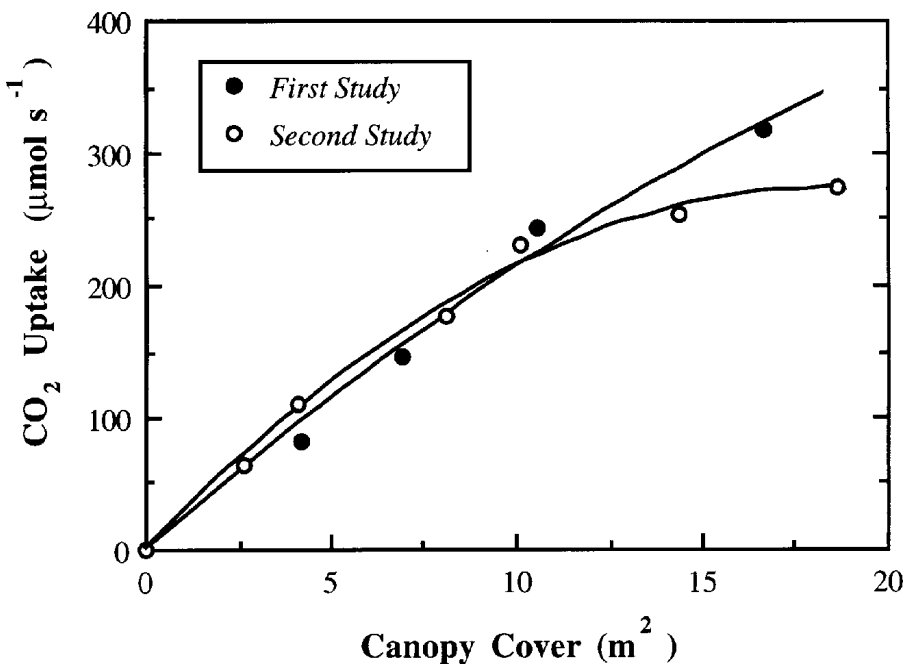

Fig. 3. Relationship between net photosynthetic $\mathrm{CO}_{2}$ uptake and canopy cover for two lettuce plantings.

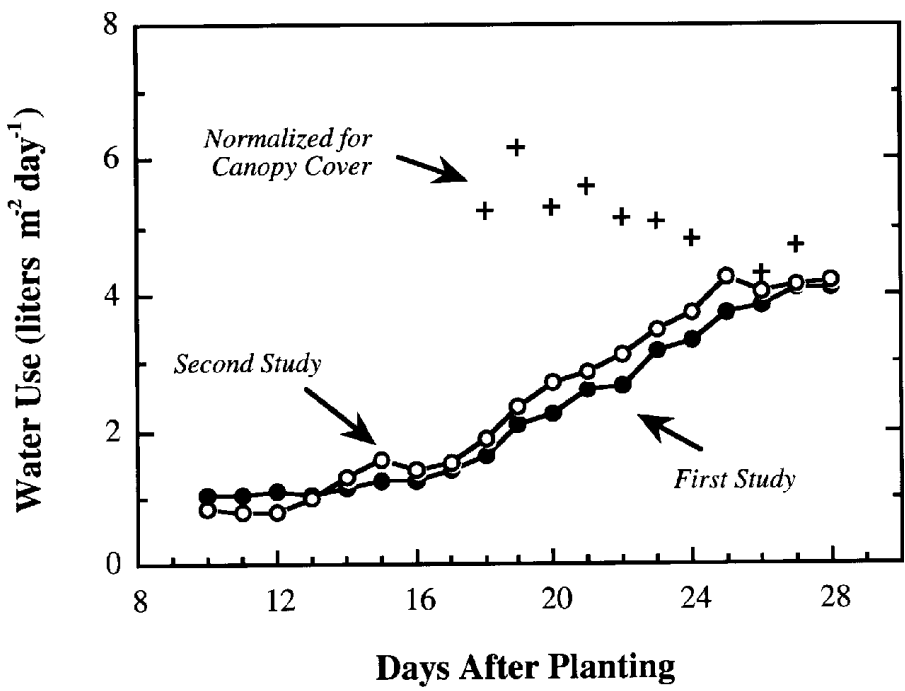

Fig. 4. Evapotranspiration for two lettuce plantings over time. Rates for the entire $20-\mathrm{m}^{2}$ area of the chamber are shown with symbols connected by lines; rates normalized to the actual canopy cover for both studies are shown as unconnected + symbols. 
cover, ET rates per unit area of canopy showed a decline between 18 and 28 DAP (Fig. 4). Final ET rates at full canopy cover for both studies averaged $\approx 4$ liters $\cdot \mathrm{m}^{-2} \cdot$ day $^{-1}$, which would equate to an average rate of $2.6 \mathrm{mmol} \cdot \mathrm{m}^{-2} \cdot \mathrm{s}^{-1}$ over a 24 -h period (Fig 4 ).

Time-course harvest data from the second study indicated that

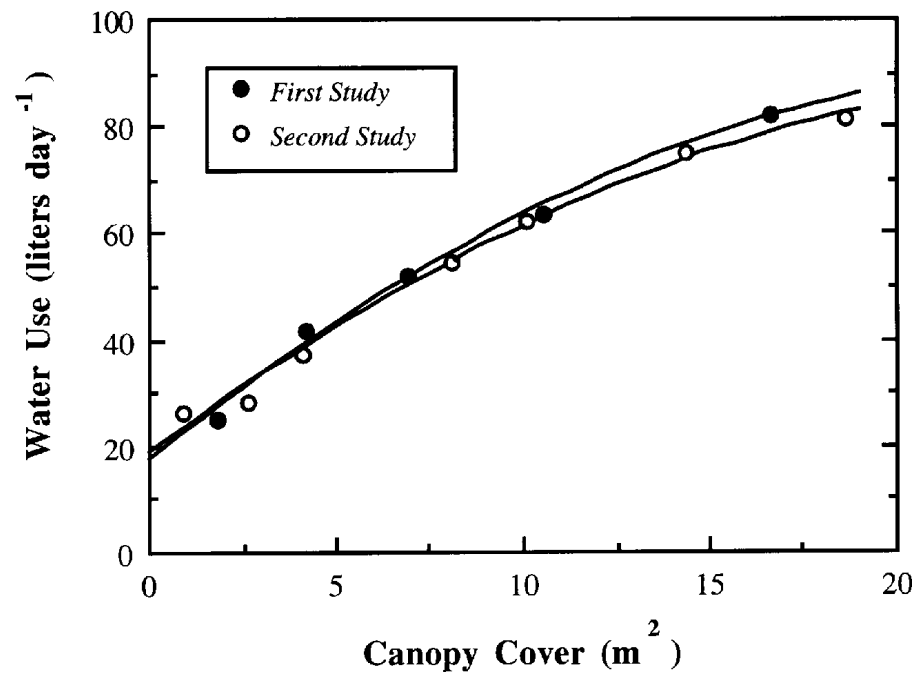

Fig. 5. Relationship between evapotranspiration and canopy cover for two lettuce plantings. The y intercept indicates the amount of direct evaporation from the hydroponic culture system before canopy establishment.

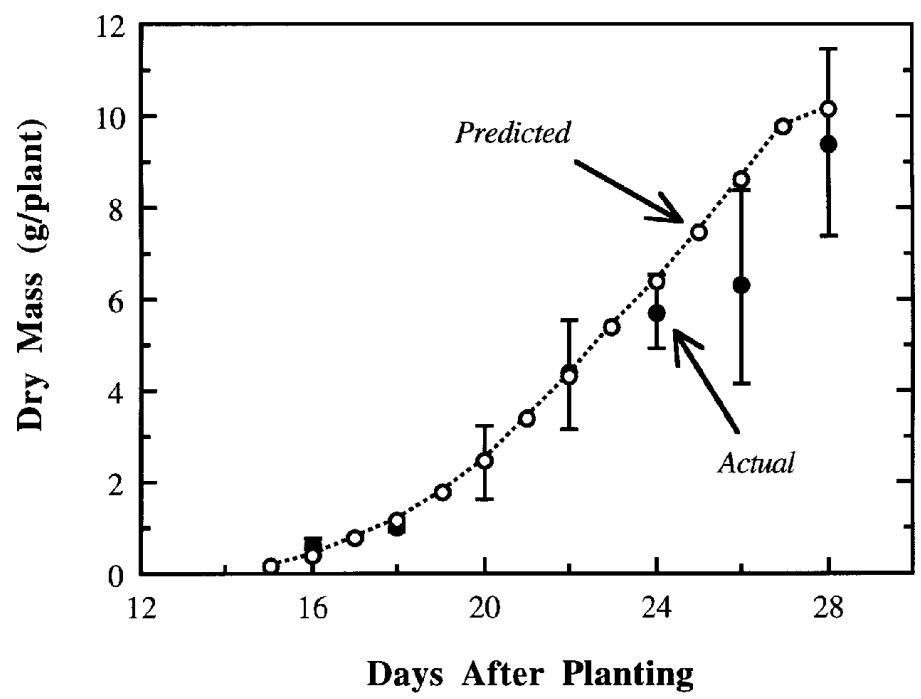

Fig. 6. Growth of lettuce plants over time in the second study. Closed symbols show actual harvest data, and open symbols with a dotted line show predicted dry mass based on canopy $\mathrm{CO}_{2}$-exchange measurements. Harvest data represent averages for four plants at each date except for final harvest at day 28, which represents the average of 360 plants. Final harvest occurred $6 \mathrm{~h}$ into the light period on day 28 . Vertical lines indicate sDs.

Table 2. Yield parameters of lettuce plants grown for 28 days in NASA's biomass production chamber.

\begin{tabular}{lcccc}
\hline \hline Study & $\begin{array}{c}\text { Shoot fresh } \\
\text { mass }\end{array}$ & $\begin{array}{c}\text { Shoot dry } \\
\text { mass }\end{array}$ & $\begin{array}{c}\text { Root dry } \\
\text { mass }\end{array}$ & $\begin{array}{c}\text { Total plant } \\
\text { dry mass }\end{array}$ \\
\hline & & (g/plant $)$ \\
First $^{z}$ & $129 \pm 32$ & $6.81 \pm 1.66$ & $0.57 \pm 0.14$ & $7.38 \pm 1.78$ \\
Second $^{y}$ & $183 \pm 39$ & $8.80 \pm 1.93$ & $0.61 \pm 0.15$ & $9.41 \pm 2.05$
\end{tabular}

${ }^{\mathrm{z} A v e r a g e s}$ of 384 plants \pm sDs; all plants grown under metal-halide lamps. ${ }^{\mathrm{y}}$ Averages of 360 plants $\pm \mathrm{SDs}$; all plants grown under high-pressure sodium lamps. plant biomass increased rapidly between 16 DAP $(\approx 5 \mathrm{~g} \mathrm{FM})$ and 28 DAP $(\approx 180 \mathrm{~g} \mathrm{FM})$ (Fig. 6). Final harvest data for the two studies are shown in Table 2. Head FM averaged $129 \mathrm{~g} / \mathrm{plant}$ and $5.3 \% \mathrm{DM}$ for the first study, and $183 \mathrm{~g} \mathrm{FM} /$ plant and $4.8 \% \mathrm{DM}$ for the second study. Total plant DM averaged $7.4 \mathrm{~g} / \mathrm{plant}$ in the first study and 9.4 $\mathrm{g} /$ plant in the second. Roots from both studies averaged $0.6 \mathrm{~g} \mathrm{DM} /$ plant, accounting for $\approx 8 \%$ and $6 \%$ of total plant DM in the first and second studies (Table 2).

Protein and crude fiber values were higher in the first study, while carbohydrate values were higher in the second study (Table 3 ); however, no statistical comparisons were made between studies since there were only two replicates from each study. Elemental analysis of leaves showed high tissue concentrations of $\mathrm{K}$ in both studies (15\% to $17 \%)$, whereas $\mathrm{P}, \mathrm{Fe}$, and $\mathrm{B}$ were higher in tissues from the first study (Table 4). No deficiencies or toxicities were apparent for any of the essential elements. Nutrient solutions in both studies were similar, with the exception of B, which was higher during the first study (Table 1). Leaf tipburn injury was first apparent at 21 DAP in the first study and at 20 DAP in the second study. At final harvest, tipburn was apparent on $49 \%$ of the plants from the first study and on $48 \%$ of the plants in the second study.

\section{Discussion}

Data from both studies indicated a trend of increasing $\mathrm{CO}_{2}$ uptake from stand photosynthesis throughout growth. The increased $\mathrm{CO}_{2}$ uptake closely followed the increase in canopy cover, suggesting that photosynthesis was limited primarily by canopy interception of PAR. During early development, each $1 \mathrm{~m}^{2}$ increase in canopy area resulted in an increase in stand $\mathrm{CO}_{2}$ uptake of 20 to $25 \mu \mathrm{mol} \cdot \mathrm{s}^{-1}$ (Fig. 3). Normalizing chamber $\mathrm{CO}_{2}$ exchange rates for actual canopy cover indicated that photosynthesis per unit canopy area declined slightly between 16 and 28 days (Fig. 1). One likely cause for this decline in photosynthetic efficiency was increased mutual shading of leaves within and between individual plants.

Integrating the total $\mathrm{CO}_{2}$ fixed during the light cycles and subtracting the total lost during the dark cycles indicated a net fixation of 107 and $122 \mathrm{~mol} \mathrm{CO}_{2}$ in the first and second studies, respectively. Combustion analysis showed that the lettuce leaf tissue was $\approx 40 \% \mathrm{C}$ by weight, which matches the percentage of $\mathrm{C}$ in the generic formula for carbohydrate, i.e., $\mathrm{CH}_{2} \mathrm{O}$ (CharlesEdwards et al., 1986). Assuming that each mole of $\mathrm{CH}_{2} \mathrm{O}$ in the biomass came from one mole of $\mathrm{CO}_{2}$, the final amount of biomass

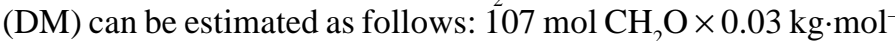
${ }^{1} \mathrm{CH}_{2} \mathrm{O}$, or $3.21 \mathrm{~kg}$ of biomass would have been produced in the

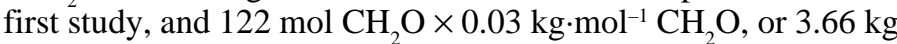
of biomass would have been produced in the second study. Actual DM yields from the first and second studies were $2.83 \mathrm{~kg}$ and 3.46 $\mathrm{kg}$, respectively (including DM from sequential harvests in the second study before the final harvest at 28 days). Thus, biomass predictions from $\mathrm{CO}_{2}$ exchange were $\approx 13 \%$ high in the first study and $6 \%$ high in the second study. A comparison of $\mathrm{CO}_{2}$ exchange estimates of biomass with the sequential harvests in the second study is shown in Fig. 6. Early estimates of standing biomass matched actual harvest data rather closely, but gas-exchange predictions overestimated yields with increasing canopy age.

Several possible sources of error may account for the overestimation of biomass from gas-exchange measurements: because gas-exchange measurements were taken from a 1-h period early in the day, rates may not have represented the average photosynthetic rates across the entire photoperiod (Wheeler, 1992). In addition, photosynthetic rates calculated from morning drawdown measure- 
Table 3. Proximate analysis of lettuce leaves grown in NASA's biomass production chamber. Data are expressed on a dry-weight basis. $^{\mathrm{z}}$

\begin{tabular}{|c|c|c|c|c|c|c|}
\hline Study & $\begin{array}{c}\text { Protein }^{\mathrm{y}} \\
(\%)\end{array}$ & $\begin{array}{l}\text { Fat } \\
(\%)\end{array}$ & $\begin{array}{c}\text { Carbohydrate } \\
(\%)\end{array}$ & $\begin{array}{l}\text { Ash } \\
(\%)\end{array}$ & $\begin{array}{c}\text { Crude fiber } \\
(\%)\end{array}$ & $\begin{array}{c}\text { Energy } \\
\text { content } \\
\left(\mathrm{kcal} \cdot \mathrm{g}^{-1}\right)\end{array}$ \\
\hline First & $30.0 \pm 0.8$ & $4.1 \pm 0.3$ & $32.7 \pm 1.6$ & $22.0 \pm 0.4$ & $11.1 \pm 0.1$ & $2.88 \pm 0.01$ \\
\hline Second & $27.2 \pm 0.2$ & $4.5 \pm 0.1$ & $37.0 \pm 0.3$ & $21.8 \pm 0.3$ & $9.4 \pm 0.2$ & $2.98 \pm 0.01$ \\
\hline
\end{tabular}

${ }^{\mathrm{z}}$ Data represent averages of two samples \pm sDs.

yTotal Kjeldahl $\mathrm{N} \times 6.25$.

Table 4. Elemental composition of lettuce leaves grown in NASA's biomass production chamber. Data are expressed on a dry-weight basis. ${ }^{\mathrm{Z}}$

\begin{tabular}{lccccccccccccc}
\hline \hline Study & $\mathrm{K}$ & $\mathrm{N}$ & $\mathrm{P}$ & $\mathrm{Ca}$ & $\mathrm{Mg}$ & $\mathrm{Zn}$ & $\mathrm{Cu}$ & $\mathrm{Fe}$ & $\mathrm{Mn}$ & $\mathrm{B}$ & $\mathrm{Mo}$ \\
\hline \multirow{3}{*}{ First } & & & & & $\left(\mu g \cdot g^{-1}\right)$ & & & & & & & \\
& 171,000 & 48,000 & 4010 & 9110 & 2950 & 36.3 & 6.00 & 128 & 53.8 & 32.1 & 0.41 \\
Second & $\pm 24,000$ & \pm 1200 & \pm 240 & \pm 1260 & \pm 160 & \pm 6.8 & \pm 1.31 & \pm 18 & \pm 112 & \pm 7.6 & \pm 0.08 \\
& 147,000 & 43,500 & 3630 & 9000 & 2890 & 30.2 & 5.75 & 68 & 41.1 & 16.9 & na $^{\mathrm{y}}$ \\
& $\pm 17,000$ & \pm 400 & \pm 230 & \pm 1270 & \pm 200 & \pm 5.1 & \pm 1.01 & \pm 23 & \pm 7.2 & \pm 3.4 & \\
\hline
\end{tabular}

${ }^{\mathrm{z}}$ Data represent averages of four samples \pm sDs.

${ }^{y}$ Not available.

ments taken later in growth (e.g., 25 to 28 DAP) starting near 1500 $\mu \mathrm{mol} \cdot \mathrm{mol}^{-1} \mathrm{CO}_{2}$ may have been higher than those at a steady-state level of $1000 \mu \mathrm{mol} \cdot \mathrm{mol}^{-1} \mathrm{CO}_{2}$. Related studies of $\mathrm{CO}_{2}$ effects on canopy gas exchange suggest that canopy photosynthetic rates of some $\mathrm{C}_{3}$ species are not yet saturated at $1000 \mu \mathrm{mol} \cdot \mathrm{mol}^{-1}$ and may be increased by raising $\mathrm{CO}_{2}$ to $1500 \mu \mathrm{mol} \cdot \mathrm{mol}^{-1}$ (Wheeler et al., 1993). An additional source of error could have been actual DM losses resulting from tissue respiration or decarboxylation during oven drying, which would result in an overestimation of biomass by gas-exchange calculations.

As for $\mathrm{CO}_{2}$ uptake, ET rates were highly dependent on canopy cover. Extrapolating ET rates to zero canopy cover gave a background rate of $\approx 20$ liters $\cdot$ day $^{-1}$ (Fig. 5). This most likely occurred from direct evaporation from exposed germination wicks and gaps between tray covers where nutrient solution was exposed to air. As the lettuce canopies reached complete closure, it is likely that most of the water flux was directly attributable to transpiration (Wheeler, 1992). Although relative humidity was higher in the first study, ET rates were similar between studies. Infrared temperature measurements indicated that leaves in the second study were $\approx 1 \mathrm{C}$ cooler than in the first. This temperature difference tended to equalize the leaf-to-air water vapor-pressure deficits between the two studies, which may explain the similar ET rates.

At full canopy cover, stand water-use efficiencies $\left(\mathrm{CO}_{2}\right.$ uptake/ ET) were $\left(17.4 \mu \mathrm{mol} \mathrm{CO}_{2} / \mathrm{m}^{2}\right.$ per sec $) /\left(2.65 \mathrm{mmol} \mathrm{H} \mathrm{O} / \mathrm{m}^{2}\right.$ per sec $)$ or $6.57 \mathrm{mmol} \mathrm{CO} / \mathrm{mol} \mathrm{H}_{2} \mathrm{O}$ for the first study, and $\left(16.1 \mu \mathrm{mol} \mathrm{CO}_{2} /\right.$ $\mathrm{m}^{2}$ per sec $) /\left(2.70 \mathrm{mmol} \mathrm{H}_{2} \mathrm{O} / \mathrm{m}^{2}\right.$ per sec $)$ or $5.96 \mathrm{mmol} \mathrm{CO} / \mathrm{mol}$ $\mathrm{H}_{2} \mathrm{O}$ for the second study. These values equate to $\approx 15 \mathrm{~g} \mathrm{CO}$ fixed/ $\mathrm{kg}$ water transpired, or $\approx 10 \mathrm{~g} \mathrm{DM} / \mathrm{kg}$ water.

A comparison of total yields showed that shoot FM was $42 \%$ greater in the second study compared to the first, while total plant DM was $28 \%$ greater. Equivalent yield from the first study occurred at $\approx 26.5$ days on the time-course harvest curve for the second study (Fig. 6), suggesting that the plants in the second study were $\approx 1.5$ days more advanced than those in the first (Fig. 2). Records for $\mathrm{CO}_{2}$-exchange rates and measurements of canopy cover showed that plants in the second study grew more during the first 2 weeks than plants in the first study. Because seed lots and planting techniques were similar between studies (seed was slightly older in the second study), the faster establishment was likely a result of environmental difference between the studies. PPF was $\approx 7 \%$ higher in the second study, which could account for much of the greater growth. Root-zone temperature was controlled and not allowed to fluctuate in the second study, which also may have promoted more rapid growth. However, Hicklenton and Wolynetz (1987) reported little effect on the growth of 'Montana' lettuce plants when root-zone temperatures were varied between 20 and 29C. Previous studies have reported little difference between HPSand $\mathrm{MH}$-grown lettuce plants at $24 \mathrm{C}$, but noted that the influence of long-wave radiation and resultant effects on leaf temperatures caused differences in growth (Sager, 1984). Differences in lamp emission spectra may have contributed to differences in growth, particularly the low amount of blue in the HPS spectrum. Lack of sufficient blue radiation has been shown to promote more rapid hypocotyl and stem elongation of lettuce and other species (Tibbitts et al., 1983; Wheeler et al., 1991). This may have caused leaves under HPS lighting to expand rapidly and intercept more light during early growth. This hypothesis is supported by findings by Koontz et al. (1987), who reported greater growth of lettuce with HPS lamps compared to relatively blue-rich cool-white fluorescent lamps at $250 \mu \mathrm{mol} \cdot \mathrm{m}^{-2} \cdot \mathrm{s}^{-1} \mathrm{PPF}$.

Proximate analyses of leaves indicated that the tissue contained high levels of protein (28\% to $30 \%$ ) and ash (22\%). Protein and ash content of field-grown lettuce typically range from $19 \%$ to $26 \%$ and $9 \%$ to $20 \%$, respectively (Duke and Atchely, 1986). The high ash levels were substantiated by direct elemental analyses, which indicated $\mathrm{K}$ concentrations of $15 \%$ to $17 \%$ in the leaf tissue (Table 4 ). The results suggest that the plants accumulated luxuriant levels of some nutrients under the conditions of these studies. It is likely that tissue nitrate levels of the hydroponically grown plants from our studies were higher than those of field-grown plants (BlomZandstra, 1989), although no direct nitrate measurements were taken. The Kjeldahl approach used to estimate total $\mathrm{N}$ and crude protein would be affected by tissue nitrate and, hence, tend to raise protein estimates.

Leaf tipburn was apparent on about one-half of the plants in both studies, although the amount of injury was considered mild. Tipburn has been related to $\mathrm{Ca}$ deficiencies in rapidly expanding lettuce leaves enclosed in heads; however, only analyses of mature shoot tissues were conducted in our studies, which would not be informative regarding $\mathrm{Ca}$ deficiency during early expansion (Barta and Tibbitts, 1991). Differences in tissue $\mathrm{Ca}$ and other elements 
occurring between studies generally were small.

Implications for CELSS. Results from these closed chamber studies suggest that lettuce should do well under controlled environment production systems that may be used in a CELSS. Although the dietary nutritional value of lettuce is considered low, its short shoot height (hence low volume requirement), ease of culture in recirculating hydroponics systems, relatively low energy requirements for lighting, and few processing requirements are notable advantages compared to other crops often discussed for CELSS. However, the relatively short harvest cycles for lettuce would require efficient space use to minimize lighting loss. For a production system, it would not be advisable to start lettuce plants at the final spacing anticipated at harvest, as was done in our studies. Future CELSS studies should explore transplant schemes or automated plant spacing systems that could be used to minimize growing area requirements and maximize light interception by crop canopies.

\section{Literature Cited}

Alexander, G.V. and L.T. McAnulty. 1981. Multielement analysis of plant-related tissues and fluids by optical emission spectrometry. J. Plant. Nutr. 3:51-59.

Association of Official Analytical Chemists. 1984. Official methods of analysis. 14th ed. Assn. Offic. Anal. Chem., Washington, D.C.

Barta, D.J. and T.W. Tibbitts. 1991. Calcium localization in lettuce leaves with and without tipburn: Comparison of controlled-environment and field-grown plants. J. Amer. Soc. Hort. Sci. 116:870-875.

Blom-Zandstra, M. 1989. Nitrate accumulation in vegetables and its relationship to quality. Ann. Applied Biol. 115: 553-561.

Charles-Edwards, D.A., D. Doley, and G.M. Rimmington. 1986. Modeling plant growth and development. Academic Press, New York.

Craker, L.E. and M. Seibert. 1983. Light and the development of 'Grand Rapids' lettuce. Can. J. Plant Sci. 63:277-281.

Duke, J.A. and A.A. Atchely. 1986. Handbook of proximate analysis tables of higher plants. CRC Press, Boca Raton, Fla.

Graves C.J. 1981. The nutrient film technique. Hort. Rev. 5:1-43.

Hammer, P.A., T.W. Tibbitts, R.W. Langhans, and J.C. McFarlane. 1978. Base-line growth studies of 'Grand Rapids' lettuce in controlled environments. J. Amer. Soc. Hort. Sci. 103:649-655.

Hicklenton, P.R. and M.S. Wolynetz. 1987. Influence of light- and dark- period air temperatures and root temperatures on growth of lettuce in nutrient flow systems. J. Amer. Soc. Hort. Sci. 112:932-935.

Knight, S.L. and C.A. Mitchell. 1983a. Enhancement of lettuce yield by manipulation of light and nitrogen nutrition. J. Amer. Soc. Hort. Sci. 108:75-754.

Knight, S.L. and C.A. Mitchell. 1988a. Growth and yield characteristics of 'Waldmann's Green' leaf lettuce under different photon fluxes from metal halide or incandescent + fluorescent radiation. Sci. Hort. 35:51-61.

Knight, S.L. and C.A. Mitchell. 1988b. Effects of $\mathrm{CO}_{2}$ and photosynthetic photon flux on yield, gas exchange and growth rate of Lactuca sativa $\mathrm{L}$. 'Waldmann's Green'. J. Expt. Bot. 39:317-328.

Koontz, H.V., R.P. Prince, and R.F. Koontz. 1987. Comparison of fluorescent and high pressure sodium lamps on growth on leaf lettuce. HortScience 22:424-425.

Morison, J.I.L. and R.M. Gifford. 1984. Ethylene contamination of $\mathrm{CO}_{2}$ cylinders. Effects on plant growth in $\mathrm{CO}_{2}$ enrichment studies. Plant Physiol. 75:275-277.

Prince, R.P., W.M. Knott, J.C. Sager, and S.E. Hilding. 1987. Design and performance of the KSC biomass production chamber. Soc. Automotive Eng. Conf., Seattle, July 1987. Tech. Paper 871437,

Prince, R.P. and W.M. Knott. 1989. CELSS Breadboard Project at the Kennedy Space Center, p. 155-163. In: D.W. Ming and D.L. Henninger (eds.). Lunar base agriculture. Amer. Soc. Agron., Madison, Wis.

Sager, J.C. 1984. Spectral effects on the growth of lettuce under controlled environment conditions. Acta Hort. 148:889-896.

Tibbitts, T.W. and D.K. Alford. 1982. Controlled ecological life support system use of higher plants. NASA Conf., Moffett Field, Calif. Publ. 2231

Tibbitts, T.W., D.C. Morgan, and I.J. Warrington. 1983. Growth of lettuce, spinach, mustard, and wheat plants under four combinations of high-pressure sodium, metal halide, and tungsten halogen lamps at equal PPFD. J. Amer. Soc. Hort. Sci. 108:622-630.

Wheeler, R.M., S.H. Schwartzkopf, T.W. Tibbitts, and R.W. Langhans. 1985. Elimination of toxicity from polyurethane foam plugs used for plant culture. HortScience 20:448-449.

Wheeler, R.M. 1992. Gas-exchange measurements using a large, closed plant growth chamber. HortScience 27:777-780.

Wheeler, R.M., K.A. Corey, J.C. Sager, and W.M. Knott. 1993. Gas exchange characteristics of wheat stands grown in a closed, controlled environment. Crop Sci. 33:161-168.

Wheeler, R.M., C.L. Mackowiak, and J.C. Sager. 1991. Soybean stem growth under high-pressure sodium with supplemental blue lighting. Agron. J. 83:903-906. 